\title{
Review
}

\section{Improvement for agronomically important traits by gene engineering}

\section{in sweetpotato}

\section{Qingchang Liu*}

Beijing Key Laboratory of Crop Genetic Improvement/Laboratory of Crop Heterosis and Utilization, Ministry of Education, China Agricultural University, Beijing 100193, China

\begin{abstract}
Sweetpotato is the seventh most important food crop in the world. It is mainly used for human food, animal feed, and for manufacturing starch and alcohol. This crop, a highly heterozygous, generally self-incompatible, outcrossing polyploidy, poses numerous challenges for the conventional breeding. Its productivity and quality are often limited by abiotic and biotic stresses. Gene engineering has been shown to have the great potential for improving the resistance to these stresses as well as the nutritional quality of sweetpotato. To date, an Agrobacterium tumefaciens-mediated transformation system has been developed for a wide range of sweetpotato genotypes. Several genes associated with salinity and drought tolerance, diseases and pests resistance, and starch, carotenoids and anthocyanins biosynthesis have been isolated and characterized from sweetpotato. Gene engineering has been used to improve abiotic and biotic stresses resistance and quality of this crop. This review summarizes major research advances made so far in improving agronomically important traits by gene engineering in sweetpotato and suggests future prospects for research in this field.
\end{abstract}

Key Words: sweetpotato (Ipomoea batatas (L.) Lam.), abiotic stresses, diseases and pests, herbicide, quality, gene engineering.

\section{Introduction}

Sweetpotato, Ipomoea batatas (L.) Lam., was originally domesticated at least $8000-10000$ years ago in tropical America (Woolfe 1992). Based on the numerical analysis of key morphological characters of sweetpotato and the wild Ipomoea species, Austin (1987) postulated that sweetpotato originated in the region between the Yucatán Peninsula of Mexico and the Orinoco River in Venezuela, within which the four major American taxa of the batatas group are distributed. Sweetpotato was introduced from the Americas into Europe by Columbus in 1492. From Europe, it was taken by the Portuguese explorers of the sixteenth century to Africa, India, Southeast Asia, and the East Indies. This crop was introduced to China in the late sixteenth century from Philippines to Fujian of China (O’Brien 1972). Other data suggest that sweetpotato was introduced to China from Vietnam, India, and Burma. From China, this crop was introduced to Japan about 400 years ago.

Sweetpotato is the seventh most important food crop in the world (FAO 2014). This crop is mainly used for human

Communicated by Makoto Tahara

Received July 29, 2016. Accepted December 24, 2016.

First Published Online in J-STAGE on February 24, 2017.

*Corresponding author (e-mail: liuqc@cau.edu.cn) food (as such or in processed form), animal feed, and for manufacturing starch and its products. It is also an alternative source of bio-energy as a raw material for fuel production. In most developing countries, it is a smallholder crop tolerant of a wide range of edaphic and climatic conditions and grown with limited inputs. Sweetpotato provides more edible energy per hectare per day than wheat, rice, or cassava and is an essential food source with very high production per capita across the relatively humid areas of Africa. Asia is the largest sweetpotato-producing region, with approximately $80 \%$ of the world's production and more than $50 \%$ of the world's area. China accounts for approximately $68 \%$ of world production, with more than $42 \%$ of the global area (FAO 2014).

Sweetpotato is a member of the family Convolvulaceae, Genus Ipomoea, section Batatas. The number of chromosomes in the sweetpotato plant is $2 n=6 x=90$. This crop, a highly heterozygous, generally self-incompatible, outcrossing polyploidy, poses numerous challenges for the conventional breeding (Cervantes-Flores et al. 2011, Dhir et al. 1998). Its productivity and quality are often limited by abiotic and biotic stresses (Zhai et al. 2016). Gene engineering has been shown to have the great potential for improving the resistance to abiotic and biotic stresses as well as the nutritional quality of sweetpotato.

In the past decades, great progress in sweetpotato gene 
Table 1. Details of recent transgenic studies on the improvement for agronomically important traits in sweetpotato

\begin{tabular}{|c|c|c|c|c|}
\hline Host cultivar & Transgene & Origin & Improved trait & Reference \\
\hline Yulmi & $C u Z n S O D, A P X$ & Sweetpotato & Drought tolerance & Li et al. 2006 \\
\hline Yulmi & $C u Z n S O D, A P X$ & Sweetpotato & Tolerance to oxidative stress and chilling & Lim et al. 2007 \\
\hline Yulmi & $S C O F-1$ & Soybean & Low temperature & Kim et al. 2011 \\
\hline Lizixiang & AtLOS5 & Arabidopsis & Salt tolerance & Gao et al. 2011c \\
\hline Xushu 18 & AtSOS & Arabidopsis & Salt tolerance & Gao et al. 2012 \\
\hline Sushu 2 & SoBADH & Spinach & Tolerance to salt, oxidative stress, and low temperature & Fan et al. 2012 \\
\hline Lizixiang & $H D G_{11}$ & Arabidopsis & Drought tolerance & Ruan et al. 2012 \\
\hline Lizixiang & IbNFU1 & Sweetpotato & Salt tolerance & Liu et al. $2014 b$ \\
\hline Kokei 14 & $I b P 5 C R$ & Sweetpotato & Salt tolerance & Liu et al. $2014 \mathrm{a}$ \\
\hline Shangshu 19 & IbMas & Sweetpotato & Salt tolerance & Liu et al. $2014 \mathrm{c}$ \\
\hline Shangshu 19 & IbSIMT1 & Sweetpotato & Salt tolerance & Liu et al. 2015 \\
\hline Xushu 22 & $A t N H X 1$ & Arabidopsis & Salt and cold tolerance & Fan et al. 2015 \\
\hline ND98 & $I b N H X 2$ & Sweetpotato & Salt and drought tolerance & Wang et al. 2016a \\
\hline Lizixiang & IbMIPS1 & Sweetpotato & Resistance to salt, drought, and stem nematodes & Zhai et al. 2016 \\
\hline Kokei 14 & $\alpha H T$ & Barley & Black rot resistance & Muramoto et al. 2012 \\
\hline Xushu 18 & $O C I$ & Rice & Stem nematode resistance & Gao et al. 2011a \\
\hline Lizixiang & $O C I$ & Rice & Stem nematode resistance & Gao et al. 2011b \\
\hline Jonathan & $O C I$ & Rice & SPFMV resistance & Cipriani et al. 2001 \\
\hline Chikei 682-11 & SPFMV-CP & SPFMV & SPFMV resistance & Okada et al. 2001 \\
\hline Blesbok & $\mathrm{CP}$ & Sweetpotato viruses & Virus resistance & Sivparsad and Gubba 2014 \\
\hline Tainung 57 & $I b N A C l$ & Sweetpotato & Herbivore resistance & Chen et al. 2016 \\
\hline Tainung 57 & IbpreproHypSys & Sweetpotato & Insect resistance & Li et al. 2016 \\
\hline Kokei 14 & Bar & Streptomyces hygroscopicus & Herbicide resistance & Otani et al. 2003 \\
\hline Yulmi & Bar & S. hygroscopicus & Herbicide resistance & Choi et al. 2007 \\
\hline Yulmi & Bar & S. hygroscopicus & Herbicide resistance & Yi et al. 2007 \\
\hline Lizixiang & Bar & S. hygroscopicus & Herbicide resistance & Zang et al. 2009 \\
\hline Kokei 14 & GBSSI & Sweetpotato & Starch composition & Kimura et al. 2001 \\
\hline Kokei 14 & $G B S S I$ & Sweetpotato & Starch composition & Otani et al. 2007 \\
\hline Kokei 14 & $I b S B E I I$ & Sweetpotato & Amylose content & Shimada et al. 2006 \\
\hline Kokei 14 & $S R F 1$ & Sweetpotato & Dry matter content & Tanaka et al. 2009 \\
\hline $\mathrm{Xu} 55-2$ & SBD2 & Sweetpotato & Starch granule morphology & Zhang et al. 2013 \\
\hline Yulmi & $I b E X P 1$ & Sweetpotato & Storage root development & Noh et al. 2013 \\
\hline Lizixiang & $I b A A T P$ & Sweetpotato & Starch structure and composition & Wang et al. 2016c \\
\hline Ayamurasaki & $L c$ & Maize & Lignification, yield and starch content & Wang et al. $2016 \mathrm{~b}$ \\
\hline Kokei 14 & NtFAD3 & Tobacco & Linolenic acid content & Wakita et al. 2001 \\
\hline Sinzami & IbOr-Ins & Sweetpotato & Carotenoid content & Park et al. 2015 \\
\hline Ayamurasaki & $I b D F R$ & Sweetpotato & Anthocyanin content, antioxidant capacity & Wang et al. 2013a \\
\hline Sinhwangmi & $I b M Y B 1$ & Sweetpotato & Anthocyanin content, antioxidant activity & Park et al. 2015 \\
\hline
\end{tabular}

engineering has been made. An Agrobacterium tumefaciensmediated transformation system has been developed for a wide range of sweetpotato genotypes. Several genes associated with abiotic stresses tolerance, diseases and pests resistance, and starch, carotenoids and anthocyanins biosynthesis have been isolated and characterized from sweetpotato. Gene engineering has been used to improve abiotic and biotic stresses resistance and nutritional quality of this crop. This review summarizes major research advances made so far in improving the resistance to abiotic stresses, diseases, pests, and herbicides and nutritional quality of sweetpotato by gene engineering (Table 1). Future prospects of research in gene engineering of this crop are also suggested.

\section{Transformation system}

An efficient genetic transformation system is very important for the successful application of gene engineering to sweetpotato improvement. Lots of studies have been done to develop an efficient transformation system in sweetpotato. Particle bombardment and electroporation were attempted for this crop, only transient gene expression, transformed calli, or a few transgenic plants were obtained (Dhir et al. 1998, Lawton et al. 2000, Okada et al. 2001, Prakash and Varadarajan 1992). Using A. rhizogenes-mediated transformation, Otani et al. (1993) observed the formation of shoots from hairy roots induced on leaf explants of five sweetpotato cultivars among 14 tested. Leaves, petioles, stems, storage roots, and embryogenic calli of sweetpotato have been used for A. tumefaciens-mediated transformation and the stable transgenic plants have also been obtained, but most of studies gave only a low transformation efficiency (Cipriani et al. 1999, Gama et al. 1996, Liu 2011, Luo et al. 2006, Morán et al. 1998, Newell et al. 1995, Otani et al. 1998, 2001, 2003, Song et al. 2004).

A few transgenic plants were produced from embryogenic suspension cultures of sweetpotato cv. Lizixiang through the use of $A$. tumefaciens strains A208SE and LBA4404 (Jiang et al. 2004, Zhai and Liu 2003). Using A. tumefaciens strain EHA105 and embryogenic suspension cultures of cv. Lizixiang, Yu et al. (2007) succeeded in developing an efficient $A$. tumefaciens-mediated transformation system of sweetpotato. Cell aggregates from embryogenic suspension 
cultures were co-cultivated with EHA105 harboring a binary vector pCAMBIA1301 with gusA and $h p t \mathrm{II}$ genes for three days. Addition of $30 \mathrm{mg} / \mathrm{l}$ acetosyringone to the cocultivation medium resulted in the significant increase of transformation efficiency. Selection culture was conducted using $25 \mathrm{mg} / \mathrm{l}$ hygromycin. Approximately 500 transgenic plants were produced from cell aggregates of one gram fresh weight with this transformation system. Thus, the A. tumefaciens strain EHA105 and embryogenic suspension cultures are strongly recommended for sweetpotato transformation. The study of Zang et al. (2009) has showed that the bar gene can be used a selectable marker gene under $0.5 \mathrm{mg} / \mathrm{l}$ phosphinothricin (PPT), which can be combined with other agronomically important genes for the improvement of sweetpotato. This A. tumefaciens-mediated transformation system with embryogenic suspension cultures is suitable for a wide range of sweetpotato genotypes (Fan et al. 2012, 2015, Gao et al. 2011c, 2012, Liu 2011, Liu et al. 2014a, 2014c, Wang et al. 2016a).

\section{Abiotic stresses tolerance}

Abiotic stresses such as salinity and drought are major environmental factors affecting crop productivity and quality worldwide (Munns and Tester 2008, Zhai et al. 2016). The development of crops with elevated levels of salinity and drought tolerance is therefore highly desirable. Though sweetpotato can grow under many different climatic conditions, its yield is often reduced by salinity and drought stresses. Especially, sweetpotato as source of bio-energy will mainly be grown on marginal land in the future, and improving its salinity and drought tolerance is therefore important for maintaining the productivity.

Osmotic stress often results in higher accumulation of proline and superoxide dismutase (SOD) and lower level of malonaldehyde (MDA), which are related to the extent of osmotic stresses tolerance (Liu et al. 2014a). Abscisic acid (ABA) accumulates extensively in plants under adverse conditions, which enhances plant resistance to environmental stresses (Ikegami et al. 2009, Xie and Yang 2003). Enhancement of the reactive oxygen species (ROS) scavenging system is expected to confer tolerance to various types of stresses in plants (Kikuchi et al. 2015, Liu et al. 2014a).

LOW OSMOTIC STRESS 5 (LOS5), which encodes a molybdenum cofactor sulfurase (MCSU), catalyzes the generation of the sulfurylated form of molybdenum cofactor, a cofactor required by aldehyde oxidase functioning in the last step of ABA biosynthesis in plants. LOS5/ABA3 is a key regulator in the tolerance of Arabidopsis to freezing, salinity, or drought stress (Xiong et al. 2001). Sweetpotato (cv. Lizixiang) plants overexpressing the AtLOS5 gene exhibited enhanced salt tolerance (Gao et al. 2011a). Their salt tolerance was evaluated with Hoagland solution containing $86 \mathrm{mM} \mathrm{NaCl}$ in a greenhouse, and the copy number of integrated AtLOS5 gene ranging from 1 to 3 was confirmed by Southern blot analysis. In Arabidopsis, ion homeostasis is mediated mainly by the salt overly sensitive (SOS), consisting of $S O S 1, S O S 2$ and $S O S 3$, signal pathway (Yang et al. 2009). Gao et al. (2012) transferred SOS1+SOS2+SOS3 to sweetpotato (cv. Xushu 18) and obtained salt-tolerant transgenic sweetpotato plants. In these studies, transgenic plants had significantly higher levels of proline, SOD, and ABA and significantly lower MDA content than those in untransformed control plants.

Late embryogenesis-abundant (LEA) proteins belong to a large group of plant proteins that are synthesized abundantly and stored during seed maturation. These proteins play a protective role under osmotic stress conditions (Ingram and Bartels 1996). Late embryogenesis abundant 14 (LEA14) cDNA was isolated from an EST library prepared from dehydration-treated fibrous roots of sweetpotato. Transgenic calli overexpressing IbLEA14 showed enhanced tolerance to drought and salt stress, suggesting that IbLEA14 might positively regulate the response to various stresses by enhancing lignification (Park et al. 2011).

Iron-sulfur cluster scaffold protein (IbNFU1), pyrroline5-carboxylate reductase (IbP5CR), maspardin (IbMas), saltinduced methyltransferase (IbSIMT1), and vacuolar $\mathrm{Na}^{+} / \mathrm{H}^{+}$ antiporters $(\mathrm{IbNHX2)}$ genes were isolated from a salttolerant sweetpotato line ND98, respectively (Liu et al. 2014b, 2014c, 2015, Wang et al. 2013b, 2016a). These five genes were introduced into sweetpotato cultivars Lizixiang, Kokei 14, Shangshu 19, Shangshu 19, and ND98, respectively, and the overexpressing plants exhibited significantly higher salt tolerance compared with the wild-type (Liu et al. 2014a, 2014b, 2014c, 2015, Wang et al. 2016a). The IbNHX2-overexpressing sweetpotato plants also showed the improved drought tolerance (Wang et al. 2016a). Proline content and SOD and photosynthesis activities were significantly increased, whereas MDA content was significantly decreased in the transgenic plants. $\mathrm{H}_{2} \mathrm{O}_{2}$ was also found to be significantly less accumulated in the transgenic plants. Their overexpression up-regulated the genes involved in stress responses, photosynthesis and ROS scavenging system. These findings suggest that these genes enhances salt and drought tolerance of the transgenic sweetpotato plants by regulating osmotic balance, protecting membrane integrity and photosynthesis and activating ROS scavenging system. These genes, especially $I b P 5 C R$, have the potential to be used for improving salinity and drought tolerance of sweetpotato and other plants. In addition, the AtNHX1 gene was introduced into sweetpotato (cv. Xushu 22) to confer salt and cold stress tolerance (Fan et al. 2015).

Myo-inositol-1-phosphate synthase (MIPS) is a key rate limiting enzyme in myo-inositol biosynthesis (Abreu and Aragáo 2007). The MIPS gene has been shown to improve the tolerance to abiotic stresses, including salt, dehydration and chilling in Arabidopsis (Joshi et al. 2013, Kaur et al. 2013), rice (Das-Chatterjee et al. 2006), tobacco (Tan et al. 2013), and Brassica juncea (Goswami et al. 2014). The IbMIPS1 gene was isolated from sweetpotato cv. Nongda 603 (Zhai and Liu 2009) and its expression was induced by 
$\mathrm{NaCl}$, polyethylene glycol (PEG), and ABA (Zhai et al. 2016). Its overexpression up-regulated the various genes involved in inositol biosynthesis, phosphatidylinositol and ABA signalling pathways, stress responses, photosynthesis and ROS scavenging system under salt and drought stresses, which significantly enhanced salt and drought tolerance in transgenic sweetpotato under field conditions (Zhai et al. 2016).

Accumulation of glycine betaine (GB) in higher plants is known to enhance the tolerance of plants to various abiotic stresses such as drought, salinity and cold (Zhang et al. 2011). The gene encoding betaine aldehyde dehydrogenase (BADH) is involved in GB biosynthesis in plants, and its overexpression increases the accumulation of GB and subsequently enhances plant tolerance to abiotic stresses (Jia et al. 2002, Park et al. 2004, Quan et al. 2004, Yang et al. 2005, Zhang et al. 2011). A chloroplastic BADH gene from Spinacia oleracea (SoBADH) was introduced into sweetpotato (cv. Sushu 2) and the transgenic plants showed improved tolerance to various abiotic stresses, including salt, oxidative stress, and low temperature (Fan et al. 2012). The increased BADH activity and GB accumulation in the transgenic plants enhanced the protection against cell damage through the maintenance of cell membrane integrity, stronger photosynthetic activity, and activation of ROS scavenging (Fan et al. 2012).

Oxidative stress is one of the major factors causing injury to plants exposed to environmental stresses. Kwak et al. (1995) and Kim et al. $(1999,2003)$ cloned a strong oxidative stress inducible peroxidase gene (SWPA2) from cultured cells of sweetpotato and subsequently characterized its function in transgenic tobacco plants and transgenic sweetpotato cultured cells subjected to environmental stresses. Transgenic sweetpotato (cv. Yulmi) plants with the enhanced tolerance to methyl viologen-mediated oxidative stress, chilling, and drought were developed by expressing the genes of both $\mathrm{CuZn}$ superoxide dismutase (CuZnSOD) and ascorbate peroxidase (APX) under the control of an oxidative stress-inducible SWPA2 promoter ( $\mathrm{Li}$ et al. 2006, Lim et al. 2007). Zinc finger proteins are associated with abiotic stress responses in plants. Transgenic sweetpotato (cv. Yulmi) plants expressing the soybean cold-inducible zinc finger protein (SCOF-1) gene under control of SWPA2 promoter showed enhanced tolerance to low-temperature stress (Kim et al. 2011).

Trehalose plays an important role in abiotic stress tolerance in plants and its biosynthesis is catalyzed by two key enzymes: trehalose-6-phosphate synthase (TPS) and trehalose-6-phosphate phosphatase (TPP). Jiang et al. (2014) isolated a TPS gene, named IbTPS, from sweetpotato (cv. Lushu 3). The IbTPS-overexpressing tobacco (cv. Wisconsin 38) plants exhibited significantly higher salt tolerance compared with the wild type. Trehalose and proline content was found to be significantly more accumulated in transgenic tobacco plants and several stress-responsive genes were up-regulated. This study suggests that IbTPS may enhance salt tolerance of plants by increasing the amount of treahalose and proline, which regulates the expression of stress-responsive genes.

Yu et al. (2008) identified a novel drought tolerance gene, HOMEODOMAIN GLABROUS 11 (HDG11), in Arabidopsis, which encodes a protein in the HD-START transcription factor family. HDG11 plays important roles in tolerance to drought and salinity stress. Ruan et al. (2012) introduced the HDG11 gene into sweetpotato (cv. Lizixiang) and found that the transgenic plants showed increased drought tolerance.

Carotenoids and anthocyanins are important antioxidants in plants and their accumulation often increases tolerance of plants to abiotic stresses. Down-regulation of the betacarotene hydroxylase (CHY-beta) and lycopene $\varepsilon$-cyclase (LCY- $\varepsilon$ ) genes, IbCHY-beta and $I b L C Y-\varepsilon$, enhanced salt tolerance of transgenic cultured cells or calli of sweetpotato due to the increased accumulation of carotenoids (Kim et al. 2012, 2013b). Transgenic calli with sweetpotato orange (IbOr) gene also exhibited increased antioxidant activity and tolerance to salt stress (Kim et al. 2013a). A sweetpotato geranylgeranyl pyrophosphate synthase (GGPS) gene, IbGGPS, enhanced osmotic stress tolerance in Arabidopsis, suggesting that this gene is involved in osmotic stress tolerance of sweetpotato (Chen et al. 2015). Down-regulation of dihydroflavonol-4-reductase (DFR) gene (IbDFR) in transgenic sweetpotato using an RNAi approach reduced antioxidant capacity due to the decreased anthocyanin accumulation compared to the wild type (Wang et al. 2013a). An orange-fleshed cultivar (Sinhwangmi) with high carotenoid levels was transformed with the IbMYB1 gene and transgenic lines displayed much higher antioxidant activities (Park et al. 2015a).

Metallothioneins (MTs) are cysteine-rich, low molecular weight, metal-binding proteins that are widely distributed in living organisms. Plants produce metal-chelating proteins such as MTs to overcome the toxic effects of heavy metals. Kim et al. (2014) cloned three MT genes, IbMT1, IbMT2, and $I b M T 3$, from sweetpotato leaves. The expression level of IbMTI and IbMT3 was strongly elevated in response to $\mathrm{Cd}$ and Fe. Furthermore, IbMT1 responded strongly to methyl viologen (MV; paraquat) and $\mathrm{NaCl}$, whereas IbMT3 was induced by low temperature and PEG. These results indicate that these genes might be involved in responses of sweetpotato to heavy metals, MV, and abiotic stresses.

\section{Diseases and pests resistance}

Numerous diseases and pests/insects have been reported on sweetpotato from different regions of the world and their species are rather different in different regions. Sweetpotato diseases generally fall into three types: bacterial, fungal, and virus. Major bacterial and fungal diseases include sclerotial blight (Sclerotium rolfsii Sacc.), black rot (Ceratocystis fimbriata Ell. \& Halst.), scurf (Monilochaetes infuscans Ell. \& Halst. ex Harter), foot rot (Plenodomus destruens Harter), 
and stem and leaf scab (Sphaceloma batatas Saw). To date, more than 20 viruses have been found to infect sweetpotato, among which sweetpotato feathery mottle virus (SPFMV) and sweetpotato chlorotic stunt virus (SPCSV) are the most common sweetpotato viruses worldwide. The mixed infection of SPFMV and SPCSV significantly decreases sweetpotato yield, and even no yield in the field if seriously infected. Aphids, whiteflies, and leafhoppers can transmit many of the viruses known to infect sweetpotato. The major pests and insects that cause considerable damage to sweetpotato are root-knot nematodes (Meloidogyne incognita var. acrita Chitwood), stem nematodes (Ditylenchus destructor Thorne), and weevil (Cylas formicarius Fab.). Other insects such as wireworms, rootworms, and flea beetles also cause damage to this crop. Sweetpotato storage roots are also injured by a complex of Coleopterous soil insects, which can cause significant economic losses (Liu et al. 2014d). In sweetpotato, several studies have been focused on the improvement for diseases and pests resistance by gene engineering.

Black rot of sweetpotato caused by pathogenic fungus Ceratocystis fimbriata severely deteriorates both plant growth and post-harvest storage of this crop. Plant thionin peptide exhibited anti-fungal activity against $C$. fimbriata. A gene for barley $\alpha$-hordothionin $(\alpha H T)$, which was placed downstream of a strong constitutive promoter of $E 12 \Omega$ or the promoter of a sweetpotato gene for $\beta$-amylase of storage roots, was introduced into sweetpotato (cv. Kokei 14).

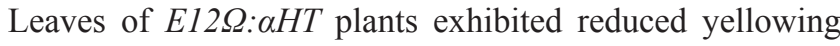
upon infection by $C$. fimbriata and storage roots of both E12Q: $\alpha H T$ and $\beta$-Amy: $\alpha H T$ plants showed reduced lesion areas around the site inoculated with $C$. fimbriata spores (Muramoto et al. 2012).

Oryzacystatin-I (OCI) protein is one member of proteinase inhibitors, which can inhibit the proteinase activity in insects' intestinal canal and prevent the assimilation of proteins (Murdock et al. 1988). It plays a role in inhibiting cysteine proteinase and may play an important role in biodefense in rice seed (Abe et al. 1987). A rice OCI gene was used to transform sweetpotato (cvs. Xushu 18 and Lizixiang, susceptible to stem nematodes) and the transgenic plants exhibited the enhanced resistance to stem nematodes compared to the untransformed control plants by the field evaluation and the inoculation test with stem nematodes, and stem nematode-resistant plants were selected from the transgenic plants (Gao et al. 2011b, 2011c).

The role of MIPS gene in resistance to biotic stresses has not been reported though it has been shown to improve tolerance to abiotic stresses in plants. Zhai et al. (2016) found that the expression of IbMIPS1 was strongly induced by stem nematodes, and its overexpression up-regulated the resistance-responsive genes, including callose synthase (CAS), peroxidase (POD), hydroxyproline-rich glycoprotein (HRGP), lipid transfer protein (LTP), leucine-rich repeat protein (LRP), proteinase inhibitor (PI), cysteine PI (CPI), and anti-microbial protein (AMP) genes, and altered the resistance-associated components (callose, lignin, $\mathrm{H}_{2} \mathrm{O}_{2}$ etc.), which resulted in significant improvement of stem nematode resistance of the transgenic sweetpotato plants. This study indicates that the IbMIPSI gene has the potential to be used to improve the resistance to stem nematodes as well as the tolerance to abiotic stresses in sweetpotato and other plants.

Okada et al. (2001) transferred the SPFMV coat protein (CP) gene to sweetpotato (cv. Chikei 682-11) and the transgenic lines showed a high resistance not only to primary but also to secondary infection by SPFMV-S, indicating that the transgenic lines with the CP gene of SPFMV-S can be used for coat protein-mediated resistance to the virus. The $O C I$ gene from rice was introduced to sweetpotato (cv. Jonathan, susceptible to SPFMV) and improved the resistance to SPFMV in the transgenic lines (Cipriani et al. 2001).

Sivparsad and Gubba (2014) developed transgenic sweetpotato (cv. Blesbok) plants with broad virus resistance. Coat protein gene segments of SPFMV, SPCSV, sweetpotato virus G (SPVG), and sweetpotato mild mottle virus (SPMMV) were used to induce gene silencing in transgenic sweetpotato. The transgenic plants were challenged by graft inoculation with SPFMV, SPCSV, SPVG, and SPMMV-infected I. setosa Ker and all of them displayed delayed and milder symptoms of chlorosis and mottling of lower leaves compared with the untransformed control plants, although virus presence was detected in them.

Sporamin is a storage protein with trypsin inhibitory activity in sweetpotato, which accounts for $85 \%$ of the soluble proteins of storage roots. Its expression in plants enhanced resistance to herbivore (Spodoptera litura) (Chen et al. 2006, 2014, Yeh et al. 1997). Chen et al. (2016) identified a 53-bp DNA region, sporamin wound-response cis-element (SWRE), in the sporamin promoter and determined its responsibility for the wounding response. The IbNAC1 gene that was specifically bound to the 50-TACAATATC-30 sequence in SWRE was isolated from a cDNA library from wounded leaves of sweetpotato. The IbNACl-overexpressing sweetpotato plants had greatly increased sporamin expression, increased trypsin inhibitory activity, and elevated resistance against herbivore. It is further demonstrated that IbNAC1 is a core transcription factor which reprograms the transcriptional response to wounding via the jasmonic acid (JA)-mediated pathway in sweetpotato.

Hydroxyproline-rich glycopeptides (HypSys) are small signaling peptides. HypSys peptides were isolated from sweetpotato and the mRNA sequence of IbpreproHypSys was identified (Chen et al. 2008). Li et al. (2016) created transgenic sweetpotatoes overexpressing and silencing (RNA interference) IbpreproHypSys and concluded that wounding induced the expression of IbpreproHypSys, whose protein product was processed into IbHypSys. IbHypSys stimulated IbpreproHypSys and ipomoelin (IPO) expression and enhanced lignin biosynthesis, which protected plants from insects. 


\section{Herbicides resistance}

Herbicide application can efficiently reduce losses of crop yield and quality caused by weed infestation. The introduction of genes coding for herbicide-detoxifying enzymes is one important genetic engineering strategy adopted for the production of herbicide-tolerant plants. The bar gene encoding phosphinothricin acetyltransferase (PAT) was isolated from the bialaphos biosynthetic pathway of Streptomyces hygroscopicus (Murakami et al. 1986). This gene is widely used for producing herbicide-resistant plants in many crop species. Transgenic crop plants expressing herbicide tolerance have been commercialized due to economically superior weed control. Weed control in the sweetpotato field after planting of cuttings is critical for high productivity. The application of bar should enable the development of herbicideresistant sweetpotato plants.

Otani et al. (2003) transferred the bar gene to sweetpotato cv. Kokei 14 and obtained transgenic plants. Leaves of freshly sprouting shoots from harvested storage roots of the transgenic plants exhibited bialaphos resistance. The bar gene was also used to transform sweetpotato $\mathrm{cv}$. Yulmi and the obtained transgenic plants remained green and healthy after spraying with Basta (Choi et al. 2007, Yi et al. 2007). Shin et al. (2011) evaluated herbicide resistance of transgenic sweetpotato plants (cv.Yulmi) and found that they were 20- to 82-fold more resistant to glufosinate than the wild-type. The representative transgenic line 7171 also showed resistance to methionine sulfoximine, but was not resistant to oxyfluorfen and paraquat.

Zang et al. (2009) successfully developed transgenic plants exhibiting functional expression of the bar gene. The copy number of integrated bar gene ranged from one to three. The transgenic plants flourished after spraying with $1000 \mathrm{mg} / \mathrm{l}$ PPT of Basta (normal field dosage) directly to the leaves, and they still survived at $2000 \mathrm{mg} / \mathrm{l}$ PPT of Basta. This study also provides a simple and efficient transformation system for sweetpotato using the bar gene as a selectable marker gene.

Transgenic plants with an enhanced expression of multiple $\mathrm{P} 450$ isoforms have the potential to improve herbicide resistance or reduce herbicide residues (Inui et al. 2000). Anwar et al. (2011) obtained transgenic sweetpotato plants expressing mammalian cytochrome P450. An in vivo herbicide tolerance assay using chlortoluron was conducted to determine the resistance of transgenic plants to herbicides. After sprayed with $17.6 \mu \mathrm{mol}$ of chlortoluron, transgenic plants exhibited the tolerance to chlortoluron, whereas the control plants were susceptible to chlortoluron.

\section{Quality improvement}

Sweetpotato is an important starch crop. The potential of this crop as a food and carbohydrate source is widely recognized (Jarret et al. 1992). Orange-fleshed sweetpotato cultivars are an excellent source of $\beta$-carotene (a vitamin A precursor) and vitamin $\mathrm{C}$, as well as fiber, iron, potassium, and protein (Low et al. 2007, Woolfe 1992). Purple sweetpotatoes are rich in anthocyanins, which are a group of very efficient bioactive compounds (Park et al. 2015b). The quality improvement for sweetpotato has been focused on breeding different types of cultivars with high content and altered composition of starch, carotenoids, or anthocyanins for their various uses.

Granule-bound starch synthase I (GBSSI) is one of the key enzymes which catalyze the formation of amylose, a linear $\alpha(1,4) \mathrm{D}$-glucan polymer, from ADP-glucose. The fulllength sense cDNA of sweetpotato GBSSI was introduced into the cultivar Kokei 14. It was found that one of the 26 transgenic plants showed the absence of amylose in the storage roots, suggesting that starch composition in sweetpotato storage roots can be altered by gene engineering (Kimura et al. 2001). Amylose-free transgenic sweetpotato plants were also produced by inhibiting sweetpotato GBSSI gene expression through RNA interference, suggesting that RNA interference is an effective method for inhibiting gene expression in the starch metabolic pathway of sweetpotato (Otani et al. 2007).

Santa-Maria et al. (2011) found that the transgenic sweetpotato plants expressing a hyperthermophilic $\alpha$-amylase showed the ability to self-process starch. No significant enzyme activity could be detected below $40^{\circ} \mathrm{C}$, but starch in the transgenic sweetpotato storage roots was readily hydrolyzed at $80^{\circ} \mathrm{C}$.

The starch-branching enzyme (SBE), 1,4- $\alpha$-D-glucan-6$\alpha$-[1,4- $\alpha$-glucan]-transferase, is a key enzyme in starch biosynthesis. The IbSBEI gene was isolated from sweetpotato and was found to be strongly expressed in storage roots, indicating that IbSBEI may work in concert with the AGPase large subunit during the primary phase of starch granule formation (Hamada et al. 2006). Shimada et al. (2006) found that the amylose content of sweetpotato starch was increased by RNA interference of the IbSBEII gene.

A plastidic ATP/ADP transporter (AATP) is responsible for importing ATP from the cytosol into plastids. In dicotyledonous plants, increasing the ATP supply is a potential way to facilitate anabolic synthesis in heterotrophic plastids. A gene encoding the AATP protein, named IbAATP, was isolated from sweetpotato. Its overexpression in sweetpotato significantly increased the starch and amylose content, led to enlarged starch granules, and altered fine structure of amylopectin, which contained an increased proportion of chains with a degree of polymerization (DP) of 10-23 and a reduced number of chains with a DP of 5-9 and 24-40 (Wang et al. 2016c). Starch from the transgenic plants also exhibited different pasting properties. In addition, the transgenic sweetpotato (cv. Xu 55-2) plants modified with an engineered tandem repeat of a family 20 starch binding domain (SBD2) exhibited the altered granule morphology without altering the primary structure of the constituent starch molecules (Zhang et al. 2013).

Sucrose non-fermenting-1-related protein kinase-1 
(SnRK1) plays an important role in plant carbohydrate metabolism and starch biosynthesis. A SnRK1 gene, named $I b S n R K 1$, was isolated from sweetpotato and its overexpression significantly increased the accumulation of sucrose, glucose, fructose, and starch in transgenic tobacco, suggesting that this gene may be applied for increasing soluble sugar and starch levels of sweetpotato (Jiang et al. 2013).

Dof proteins are a plant specific family of zinc finger transcriptional factors, containing a highly conserved DNAbinding motif called the Dof domain. Tanaka et al. (2009) isolated the sweetpotato SRF1 gene and the SRF1overexpressing sweetpotato plants showed significantly higher storage root dry matter content compared to the original cultivar Kokei 14. The starch content per fresh weight of the storage roots was also higher than that of the wildtype plants, while the glucose and fructose content drastically decreased. These results suggest that $S R F 1$ modulates the carbohydrate metabolism in the storage roots of sweetpotato and has the potential to be used in improving starch content of this crop.

Wang et al. (2016b) found that ectopic expression of the maize anthocyanin regulator Lc in sweetpotato increased lignification in adventitious roots and in developing storage roots, which was accompanied by significant yield reduction as well as repression of starch accumulation in the developing storage roots. Thus, it is thought that a cause-andeffect relationship between increased lignification and reduced storage root yield exists and lignification competes with starch accumulation for the distribution of photoassimilates in developing storage roots. In addition, Wakita et al. (2001) found the transgenic sweetpotato plants expressing a tobacco microsomal $\omega-3$ fatty acid desaturase gene (NtFAD3) driven by the El $2 \Omega$ promoter showed the increased linolenic acid content. Noh et al. (2013) found that an expansin gene (IbEXP1) played a negative role in the formation of sweetpotato storage roots by suppressing the proliferation of metaxylem and cambium cells to inhibit the initial thickening growth of storage roots. These findings are beneficial to improving the quality and yield of sweetpotato by gene engineering.

beta-Carotene hydroxylase (CHY-beta) is a key regulatory enzyme in the beta-beta-branch of carotenoid biosynthesis. Down-regulation of the CHY-beta gene increased betacarotene and total carotenoids in transgenic cultured cells of sweetpotato (Kim et al. 2012). Lycopene $\varepsilon$-cyclase (LCY- $\varepsilon$ ) is involved in the first step of the $\alpha$-branch synthesis pathway of carotenoids from lycopene. Down-regulation of $L C Y-\varepsilon$ increased carotenoid synthesis via the $\beta$-branchspecific pathway in the transgenic calli of sweetpotato (Kim et al. 2013b). Yu et al. (2013) cloned the IbLCYe gene from sweetpotato cv. Nongdafu 14 with high carotenoid content. Transgenic tobacco (cv. Wisconsin 38) expressing IbLCYe accumulated significantly more beta-carotene, showing that IbLCYe has an important function for the accumulation of carotenoids of sweetpotato. The formation of geranyl pyrophosphate and geranylgeranyl pyrophosphate (GGPP) is a key step in biosynthetic pathway of carotenoids and many other terpenes. This step is catalyzed by geranylgeranyl pyrophosphate synthase (GGPS) (Hirschberg 2001). A cDNA namely $I b G G P S$ was cloned from the storage roots of sweetpotato and its overexpression in Arabidopsis increased the content of total carotenoids (Chen et al. 2015). The $\mathrm{IbOr}$ gene is involved in the accumulation of carotenoids. Sweetpotato plants overexpressing IbOr-Ins in an anthocyaninrich purple-fleshed cultivar Sinzami exhibited increased carotenoid levels (up to 7-fold) in their storage roots (Park et al. 2015b).

Anthocyanidin synthase (ANS), a 2-oxoglutarate (2OG) iron-dependent oxygenase, catalyzes the penultimate step in the biosynthesis of anthocyanin, which is responsible for the formation of the colored anthocyanidins from the colorless leucoanthocyanidins (Welford et al. 2005). A full-length cDNA, designated I $B A N S$, was isolated from purple-fleshed sweetpotato cv. Yamakawamurasaki, and its expression was highest in storage roots and most abundant during the formation of storage roots, suggesting that this gene is associated with anthocyanin biosynthesis in sweetpotato (Zhou et al. 2010). The IbANS gene was also cloned from purplefleshed sweetpotato cv. Yuzi 263 (Liu et al. 2010). MADSbox proteins of known function are transcription factors, which play a range of fascinating biological roles. A MADS-box gene, IbMADS10, was cloned from sweetpotato (cv. Beniazuma) and was shown to be involved in the accumulation of anthocyanin (Lalusin et al. 2006). These genes have the potential to be used to increase the content of anthocyanin in sweetpotato.

MYB transcriptional factors have been identified in various plant species as regulators of flavonoid biosynthesis in flowers, seeds, and fruits. Mano et al. (2007) isolated the MYB genes IbMYB1 and IbMYB2 from purple-fleshed sweetpotato cv. Ayamurasaki and suggested that IbMYBI controls anthocyanin biosynthesis specifically in the flesh of sweetpotato storage roots. An orange-fleshed cultivar Sinhwangmi with high carotenoid levels was transformed with the IbMYBI gene and the transgenic lines displayed much higher level of anthocyanin (Park et al. 2015a).

Dihydroflavonol-4-reductase (DFR) is a key enzyme in the catalysis of the stereospecific reduction of dihydroflavonols to leucoanthocyanidins in anthocyanin biosynthesis. Down-regulation of $I b D F R$ in transgenic sweetpotato using an RNAi approach dramatically reduced anthocyanin accumulation in young leaves, stems, and storage roots (Wang et al. 2013a).

Guo et al. (2015) isolated a full-length cDNA of chalcone isomerase $(\mathrm{IbCHI})$ from sweetpotato cv. Yamakawamurasaki and think that $I b C H I$ is a key enzyme in the anthocyanin biosynthetic pathway of sweetpotato, which is responsible for the activation of anthocyanin biosynthesis in the early stage of storage root development.

In addition, genetic linkage maps of sweetpotato have been developed based on randomly amplified polymorphic DNA (RAPD), amplified fragment length polymorphism 
(AFLP), sequence-related amplified polymorphism (SRAP), and simple sequence repeat (SSR) markers (CervantesFlores et al. 2008, Kriegner et al. 2003, Li et al. 2010b, Ukoskit and Thompson 1997, Zhao et al. 2013). Several major quantitative trait loci (QTLs) for storage root yield, starch content, and carotene content of sweetpotato have been also identified (Cervantes-Flores et al. 2011, Li et al. 2010a, 2014, Yu et al. 2014, Zhao et al. 2013). These studies represent an important step forward in cloning genes for the storage root yield and nutritional quality of sweetpotato and improving the yield and quality of this crop by gene engineering.

\section{Conclusions and future prospects}

A. tumefaciens-mediated transformation has been established using embryogenic suspension cultures of sweetpotato. Several important genes associated with abiotic and biotic stresses resistance and quality traits have been isolated and characterized from sweetpotato. Sweetpotato plants with the improved resistance to salt, drought, oxidative stress, low temperature, diseases, pests, and herbicides and increased content of starch, carotenoids, and anthocyanins have been produced by gene engineering, although engineering genetically modified (GM) sweetpotatoes have not been applied in the production of this crop to date. Gene engineering has shown its great potential for improving the resistance to abiotic and biotic stresses and the nutritional quality of sweetpotato.

Sweetpotato is a highly heterozygous, generally selfincompatible, outcrossing, and vegetatively propagated autohexaploid. Although there are many available genes from other plant species, exploring new genes from sweetpotato and its wild relatives is necessary for the sweetpotato breeding program and incorporating abiotic and biotic stresses resistance and high quality. Genomic approaches have been used for discovering the important genes involved in plant secondary metabolism pathways. The sweetpotato genome is still unavailable. A further goal for the near future should be to obtain the complete sequence of the sweetpotato genome. Transcriptome sequencing is an efficient way for discovering and characterizing novel enzymes and transcription factors from sweetpotato, which provides an important transcriptional data source for studying storage root formation, flower development, abiotic and biotic resistance, and starch, carotenoids, and anthocyanins biosynthesis and characterizing the important responsible genes of this crop (Firon et al. 2013, Li et al. 2015, Schafleitner et al. 2010, Tao et al. 2012, 2013, Wang et al. 2010, Xie et al. 2012). QTL analysis has become an efficient method to identify responsible genes by generating transformants of the corresponding DNA region. Fine mapping of major QTLs for storage root yield and nutritional quality is vitally important for their further isolation and utilization. Introduction of agronomically important genes to commercial sweetpotato cultivars will be conducted in a large scale for these genes to be utilized for the improvement of sweetpotato. Conventional breeding methods and molecular techniques should be used together to develop sweetpotato cultivars with the improved resistance to abiotic and biotic stresses and increased nutritional quality.

\section{Acknowlegments}

This work was supported by China Agriculture Research System (CARS-11, Sweetpotato). This review covers major but not all research advances made so far in improving agronomically important traits by gene engineering in sweetpotato. I thank all of the sweetpotato researchers for their excellent work.

\section{Literature Cited}

Abe, K., Y.Emori, H.Kondo, K. Suzuki and S.Arai (1987) Molecular cloning of a cysteine proteinase inhibitor of rice (oryzacystatin): homology with animal cystatins and transient expression in the ripening process of rice seeds. J. Biol. Chem. 262: 16793-16797.

Abreu, E.F.M. and F.J.Aragáo (2007) Isolation and characterization of a myoinositol-1-phosphate synthase gene from yellow passion fruit (Passiflora edulis f. flavicarpa) expressed during seed development and environmental stress. Ann. Bot. 99: 285-292.

Anwar, N., K.N. Watanabe and J.A. Watanabe (2011) Transgenic sweetpotato expressing mammalian cytochrome P450. Plant Cell Tissue Organ Cult. 105: 219-231.

Austin, D.F. (1987) The taxonomy, evolution and genetic diversity of sweetpotatoes and related wild species. In: Gregory, P. (ed.) Exploration, Maintenance, and Utilization of Sweetpotato Genetic Resources. Lima, Peru: CIP, pp. 27-60.

Cervantes-Flores, J.C., G.C. Yencho, A. Kriegner, K.V.Pecota, M.A. Faulk, R.O.M. Mwanga and B.R. Sosinski (2008) Development of a genetic linkage map and identification of homologous linkage groups in sweetpotato using multiple-dose AFLP markers. Mol. Breed. 21: 511-532.

Cervantes-Flores, J.C., B. Sosinski, K.V.Pecota, R.O.M. Mwanga, G.L. Catignani, V.D. Truong, R.H. Watkins, M.R. Ulmer and G.C. Yencho (2011) Identification of quantitative trait loci for dry-matter, starch, and $\beta$-carotene content in sweetpotato. Mol. Breed. 28: 201-216.

Chen, H.J., S.J.Wang, C.C.Chen and K.W. Yeh (2006) New genzhaie construction strategy in T-DNA vector to enhance expression level of sweetpotato sporamin and insect resistance in transgenic Brassica oleracea. Plant Sci. 171: 367-374.

Chen, P.J., R. Senthilkumar, W.N.Jane, Y.He, Z.Tian and K.W.Yeh (2014) Transplastomic Nicotiana benthamiana plants expressing multiple defense genes encoding protease inhibitors and chitinase display broad-spectrum resistance against insects, pathogens and abiotic stresses. Plant Biotechnol. J. 12: 503-515.

Chen, S.P., I.W.Lin, X.Y.Chen, Y.H. Huang, S.C.Chang, H.S. Lo, H.H. $\mathrm{Lu}$ and K.W.Yeh (2016) Sweetpotato NAC transcription factor, IbNAC1, upregulates sporamin gene expression by binding the SWRE motif against mechanical wounding and herbivore attack. Plant J. 86: 234-248.

Chen, W., S.Z.He, D.G.Liu， G.B.Patil， H.Zhai， F.B.Wang, T.J. Stephenson, Y.N.Wang, B.Wang, B.Valliyodan et al. (2015) A sweetpotato geranylgeranyl pyrophosphate synthase gene, IbGGPS, increases carotenoid content and enhances osmotic stress tolerance in Arabidopsis thaliana. PLoS ONE 10: e0137623. 
Chen, Y.C., W.F. Siems, G.Pearce and C.A. Ryan (2008) Six peptide wound signals derived from a single precursor protein in Ipomoea batatas leaves activate the expression of the defense gene sporamin. J. Biol. Chem. 283: 11469-11476.

Choi, H.J., T. Chandrasekhar, H.Y.Lee and K.M.Kim (2007) Production of herbicide-resistant transgenic sweetpotato plants through Agrobacterium tumefaciens method. Plant Cell Tissue Organ Cult. 91: 235-242.

Cipriani, G., D.Michaud, F.Brunelle, A. Golmirzaie and D.P.Zhang (1999) Expression of soybean proteinase inhibitor in sweetpotato. CIP Program Rep. 1997-1998: 271-277.

Cipriani, G., S.Fuentes, V.Bello, L.F.Salazar, M. Ghislain and D.P. Zhang (2001) Transgene expression of rice cysteine proteinase inhibitors for the development of resistance against sweetpotato feathery mottle virus. CIP Program Rep. 1999-2000: 267-271.

Das-Chatterjee,A., L. Goswami, S. Maitra, K.G.Dastidar, S. Ray and A.L. Majumder (2006) Introgression of a novel salt-tolerant L-myo-inositol 1-phosphate synthase from Porteresia coarctata (Roxb.) Tateoka (PcINO1) confers salt tolerance to evolutionary diverse organisms. FEBS Lett. 580: 3980-3988.

Dhir, S.K., J. Oglesby and A.S. Bhagsari (1998) Plant regeneration via somatic embryogenesis, and transient gene expression in sweetpotato protoplasts. Plant Cell Rep. 17: 665-669.

Fan, W.J., M.Zhang, H.X.Zhang and P.Zhang (2012) Improved tolerance to various abiotic stresses in transgenic sweetpotato (Ipomoea batatas) expressing spinach betaine aldehyde dehydrogenase. PLoS ONE 7: e37344.

Fan, W.J., G.F. Deng, H.X. Wang, H.X. Zhang and P.Zhang (2015) Elevated compartmentalization of $\mathrm{Na}^{+}$into vacuoles improves salt and cold stress tolerance in sweetpotato (Ipomoea batatas). Physiol. Plant. 154: 560-571.

FAO (2014) www.fao.org/giews/english/fo/index.htm.

Firon, N., D.LaBonte, A.Villordon, Y.Kfir, J.Solis, E.Lapis, T.S. Perlman, A. Doron-Faigenboim, A. Hetzroni, L.Althan et al. (2013) Transcriptional profiling of sweetpotato (Ipomoea batatas) roots indicates down-regulation of lignin biosynthesis and up-regulation of starch biosynthesis at an early stage of storage root formation. BMC Genomics 14: 460.

Gama, M.I.C.S., R.P. Jr. Leite, A.R. Cordeiro and D.J.Cantliffe (1996) Transgenic sweetpotato plants obtained by Agrobacterium tumefaciens-mediated transformation. Plant Cell Tissue Organ Cult. 46: 237-244.

Gao, S., L.Yuan, H.Zhai, C.L.Liu, S.Z.He and Q.C.Liu (2011a) Transgenic sweetpotato plants expressing an LOS5 gene are tolerant to salt stress. Plant Cell Tissue Organ Cult. 107: 205-213.

Gao, S., B. Yu, L. Yuan, H.Zhai, S.Z.He and Q.C.Liu (2011b) Production of transgenic sweetpotato plants resistant to stem nematodes using oryzacystatin-I gene. Sci. Hortic. 128: 408-414.

Gao, S., B.Yu, H.Zhai, S.Z.He and Q.C.Liu (2011c) Enhanced stem nematode resistance of transgenic sweetpotato plants expressing oryzacystatin-I gene. Agric. Sci. China 10: 519-525.

Gao, S., L. Yuan, H.Zhai, C.L.Liu, S.Z.He and Q.C.Liu (2012) Overexpression of SOS genes enhanced salt tolerance in sweetpotato. J. Integr. Agric. 11: 378-386.

Goswami,L., S. Sengupta, S. Mukherjee, S.Ray, R. Mukherjee and A.L.Majumder (2014) Targeted expression of L-myo-inositol 1-phosphate synthase from Porteresia coarctata (Roxb.) Tateoka confers multiple stress tolerance in transgenic crop plants. J. Plant Biochem. Biotechnol. 23: 316-330.

Guo, J.Y., W.Zhou, Z.L.Lu, H.Li, H.H.Li and F. Gao (2015) Isolation and functional analysis of chalcone isomerase gene from purple- fleshed sweetpotato. Plant Mol. Biol. Rep. 33: 1451-1463.

Hamada, T., S.H.Kim and T. Shimada (2006) Starch-branching enzyme I gene (IbSBEI) from sweetpotato (Ipomoea batatas): molecular cloning and expression analysis. Biotechnol. Lett. 28: 12551261.

Hirschberg, J. (2001) Carotenoid biosynthesis in flowering plants. Curr. Opin. Plant Biol. 4: 210-218.

Ikegami, K., M. Okamoto, M. Seo and T. Koshiba (2009) Activation of abscisic acid biosynthesis in the leaves of Arabidopsis thaliana in response to water deficit. J. Plant Res. 122: 235-243.

Ingram, J. and D. Bartels (1996) The molecular basis of dehydration tolerance in plants. Annu. Rev. Plant Physiol. Plant Mol. Biol. 47: 377-403.

Inui, H., T. Kodama, Y. Ohkawa and H. Ohkawa (2000) Herbicide metabolism and cross-tolerance in transgenic potato plants co-expressing human CYP1A1, CYP2B6, and CYP2C19. Pestic. Biochem. Physiol. 66: 116-129.

Jarret, R.L., N. Gawel and A. Whittemore (1992) Phylogenetic relationships of the sweetpotato [Ipomoea batatas (L.) Lam.]. J. Am. Soc. Hortic. Sci. 117: 633-637.

Jia, G.X., Z.Q.Zhu, F.Q. Chang and Y.X.Li (2002) Transformation of tomato with the $B A D H$ gene from Atriplex improves salt tolerance. Plant Cell Rep. 21: 141-146.

Jiang, S.J., Q.C.Liu, H.Zhai, L.S. Wu and Y.P. Wang (2004) Regeneration of sweet potato transgenic plants with oryzacystatin-I (OCI) gene. J. Agr. Biotechnol. 12: 34-37.

Jiang, T., H.Zhai, F.B. Wang, N.Yang, B. Wang, S.Z.He and Q.C. Liu (2013) Cloning and characterization of a carbohydrate metabolismassociated gene IbSnRK1 from sweetpotato. Sci. Hortic. 158: 2232.

Jiang, T., H.Zhai, F.B. Wang, H.N.Zhou, Z.Z.Si, S.Z.He and Q.C. Liu (2014) Cloning and characterization of a salt tolerance-associated gene encoding trehalose-6-phosphate synthase in sweetpotato. J. Integr. Agric. 13: 1651-1661.

Joshi, R., M.V.Ramanarao and N.Baisakh (2013) Arabidopsis plants constitutively overexpressing a myo-inositol 1-phosphate synthase gene (SaINO1) from the halophyte smooth cordgrass exhibits enhanced level of tolerance to salt stress. Plant Physiol. Biochem. 65: 61-66.

Kaur, H., P. Verma, B.P. Petla, V. Rao, S.C. Saxena and M. Majee (2013) Ectopic expression of the ABA-inducible dehydration-responsive chickpea L-myo-inositol 1-phosphate synthase 2 (CaMIPS2) in Arabidopsis enhances tolerance to salinity and dehydration stress. Planta 237: 321-335.

Kikuchi,A., H.D. Huynh, T. Endo and K. Watanabe (2015) Review of recent transgenic studies on abiotic stress tolerance and future molecular breeding in potato. Breed. Sci. 65: 85-102.

Kim, K.Y., G.H.Huh, H.S.Lee, S.Y.Kwon, Y.Hur and S.S.Kwak (1999) Molecular characterization of cDNAs for two anionic peroxidases from suspension cultures of sweet potato. Mol. Gen. Genet. 261: 941-947.

Kim,K.Y., S.Y.Kwon, H.S.Lee, Y.Hur, J.W.Bang and S.S.Kwak (2003) A novel oxidative stresss-inducible peroxidase promoter from sweet potato: molecular cloning and characterization in transgenic tobacco plants and cultured cells. Plant Mol. Biol. 51: 831838.

Kim, S.H., Y.O.Ahn, M.J.Ahn, H.S. Lee and S.S. Kwak (2012) Downregulation of beta-carotene hydroxylase increases beta-carotene and total carotenoids enhancing salt stress tolerance in transgenic cultured cells of sweetpotato. Phytochemistry 74: 69-78.

Kim, S.H., Y.O.Ahn, M.J.Ahn, J.C.Jeong, H.S.Lee and S.S.Kwak 
(2013a) Cloning and characterization of an Orange gene that increases carotenoid accumulation and salt stress tolerance in transgenic sweetpotato cultures. Plant Physiol. Biochem. 70: 445-454.

Kim, S.H., Y.H.Kim, Y.O.Ahn, M.J.Ahn, J.C.Jeong, H.S.Lee and S.S. Kwak (2013b) Downregulation of the lycopene $\varepsilon$-cyclase gene increases carotenoid synthesis via the $\beta$-branch-specific pathway and enhances salt-stress tolerance in sweetpotato transgenic calli. Physiol. Plant. 147: 432-442.

Kim, S.H., J.C. Jeong, Y.O.Ahn, H.S.Lee and S.S. Kwak (2014) Differential responses of three sweetpotato metallothionein genes to abiotic stress and heavy metals. Mol. Biol. Rep. 41: 6957-6966.

Kim, Y.H., M.D.Kim, S.C.Park, K.S. Yang, J.C.Jeong, H.S.Lee and S.S.Kwak (2011) SCOF-1-expressing transgenic sweetpotato plants show enhanced tolerance to low-temperature stress. Plant Physiol. Biochem. 49: 1436-1441.

Kimura, T., M. Otani, T. Noda, O. Ideta, T. Shimada and A. Saito (2001) Absence of amylose in sweetpotato [Ipomoea batatas (L.) Lam.] following the introduction of granule-bound starch synthase cDNA. Plant Cell Rep. 20: 663-666.

Kriegner,A., J.C.Cervantes, K. Burg, R.O.M.Mwanga and D.Zhang (2003) A genetic linkage map of sweetpotato [Ipomoea batatas (L.) Lam.] based on AFLP markers. Mol. Breed. 11: 169-185.

Kwak, S.S., S.K.Kim, M.S.Lee, K.H.Jung, I.H.Park and J.R.Liu (1995) Three acidic peroxidases from suspension-cultures of sweet potato. Phytochemistry 39: 981-984.

Lalusin,A.G., K.Nishita, S.H. Kim, M.Ohta and T.Fujimura (2006) A new MADS-box gene (IbMADS10) from sweetpotato (Ipomoea batatas (L.) Lam.) is involved in the accumulation of anthocyanin. Mol. Genet. Genomics 275: 44-54.

Lawton, R., S. Winfield, H. Daniell, A.S. Bhagsari and S.K. Dhir (2000) Expression of green-fluorescent protein gene in sweetpotato tissues. Plant Mol. Biol. Rep. 18: 139a-139i.

Li,A.X., Q.C.Liu, Q.M.Wang, H.Zhai, W.Z.Yan, H.Y.Zhang and M.Li (2010a) Mapping QTLs for starch content in sweetpotato. Mol. Plant Breed. 8: 516-520.

Li,A.X., Q.C.Liu, Q.M.Wang, L.M.Zhang, H.Zhai and S.Z.Liu (2010b) Establishment of molecular linkage maps using SRAP markers in sweetpotato. Acta Agric. Sin. 36: 1286-1295.

Li, H., N.Zhao, X.X.Yu, Y.X.Liu, H.Zhai, S.Z.He, Q.Li, D.F. Ma and Q.C.Liu (2014) Identification of QTLs for storage root yield in sweetpotato. Sci. Hortic. 170: 182-188.

Li, R.J., H.Zhai, C.Kang, D.G.Liu, S.Z.He and Q.C.Liu (2015) De novo transcriptome sequencing of the orange-fleshed sweetpotato and analysis of differentially expressed genes related to carotenoid biosynthesis. Int. J. Genomics 2015: 843802.

Li, Y., X.P. Deng, S.S. Kwak and K. Tanaka (2006) Drought tolerance of transgenic sweetpotato expressing both $\mathrm{Cu} / \mathrm{Zn}$ superoxide dismutase and ascorbate peroxidase. J. Plant Physiol. Mol. Biol. 32: 451-457.

Li, Y.C., W.L. Wan, J.S.Lin, Y.W. Kuo, Y.C. King, Y.C.Chen and S.T. Jeng (2016) Signal transduction and regulation of IbpreproHypSys in sweetpotato. Plant Cell Environ. 39: 1576-1587.

Lim, S., Y.H. Kim, S.H. Kim, S.Y. Kwon, H.S. Lee, J.S. Kim, K.Y.Cho, K.Y.Paek and S.S. Kwak (2007) Enhanced tolerance of transgenic sweetpotato plants that express both CuZnSOD and APX in chloroplasts to methyl viologen-mediated oxidative stress and chilling. Mol. Breed. 19: 227-239.

Liu,D.G., S.Z.He, H.Zhai, L.J.Wang, Y.Zhao, B.Wang, R.J.Li and Q.C.Liu (2014a) Overexpression of IbP5CR enhances salt tolerance in transgenic sweetpotato. Plant Cell Tissue Organ Cult. 117: $1-16$.
Liu, D.G., L.J. Wang, C.L. Liu, X.J. Song, S.Z.He, H. Zhai and Q.C. Liu (2014b) An Ipomoea batatas iron-sulfur cluster scaffold protein gene, IbNFU1, is involved in salt tolerance. PLoS ONE 9: e93935.

Liu, D.G., L.J.Wang, H.Zhai, X.J. Song, S.Z.He and Q.C. Liu (2014c) A novel $\alpha / \beta$-hydrolase gene IbMas enhances salt tolerance in transgenic sweetpotato. PLoS ONE 9: e115128.

Liu,D.G., S.Z.He, X.J.Song, H.Zhai, N.Liu, D.D.Zhang, Z.T.Ren and Q.C.Liu (2015) IbSIMT1, a novel salt-induced methyltransferase gene from Ipomoea batatas, is involved in salt tolerance. Plant Cell Tissue Organ Cult. 120: 701-715.

Liu, Q.C. (2011) Sweetpotato omics and biotechnology in China. Plant Omics J. 4: 295-301.

Liu, Q.C., J.Liu, P.Zhang and S.Z.He (2014d) Root and tuber crops. In: Van Alfen, N. (ed.) Encyclopedia of Agriculture and Food Systems, Vol. 5, Elsevier, San Diego, pp. 46-61.

Liu, X.Q., M.Chen, M.Y.Li, C.X.Yang, Y.F.Fu, Q.T.Zhang, L.J.Zeng and Z.H.Liao (2010) The anthocyanidin synthase gene from sweetpotato (Ipomoea batatas (L.) Lam.): cloning, characterization and tissue expression analysis. Afr. J. Biotechnol. 9: 3748-3752.

Low, J., M. Arimond, N. Osman, B. Cungara, F.Zano and D. Tschirley (2007) A food-based approach introducing orange-fleshed sweetpotatoes increased vitamin A intake and serum retinol concentrations in young children in rural Mozambique. J. Nutr. 137: 13201327.

Luo, H.R., M. Santa Maria, J.Benavides, D.P.Zhang, Y.Z.Zhang and M. Ghislain (2006) Rapid genetic transformation of sweetpotato (Ipomoea batatas (L.) Lam.) via organogenesis. Afr. J. Biotechnol. 5: $1851-1857$.

Mano, H., F. Ogasawara, K. Sato, H. Higo and Y. Minobe (2007) Isolation of a regulatory gene of anthocyanin biosynthesis in tuberous roots of purple-fleshed sweetpotato. Plant Physiol. 143: 12521268.

Morán,R., R. García, A.López, Z.Zaldúa, J.Mena, M.García, R. Armas, D. Somonte, J.Rodríguez, M. Gómez et al. (1998) Transgenic sweetpotato plants carrying the delta-endotoxin gene from Bacillus thuringiensis var. tenebrionis. Plant Sci. 139: 175-184.

Munns, R. and M. Tester (2008) Mechanisms of salinity tolerance. Annu. Rev. Plant Biol. 59: 651-681.

Murakami, T., H.Anzai, S.Imai, A.Satoh, K. Nagoaka and C.J. Thompson (1986) The bialaphos biosynthetic genes of Streptomyces hygroscopicus: molecular cloning and characterization of the gene cluster. Mol. Gen. Genet. 205: 42-50.

Muramoto, N., T. Tanaka, T. Shimamura, N. Mitsukawa, E. Hori, K.Koda, M.Otani, M.Hirai, K. Nakamura and T.Imaeda (2012) Transgenic sweetpotato expressing thionin from barley gives resistance to black rot disease caused by Ceratocystis fimbriata in leaves and storage roots. Plant Cell Rep. 31: 987-997.

Murdock, L.L., R.E. Shade and M.A. Pomeroy (1988) Effects of E-64, a cysteine proteinase inhibitor, on cowpea weevil growth, development, and fecundity. Environ. Entomol. 17: 467-469.

Newell, C.A., J.M.Lowe, A. Merryweather, L.M. Rooke and W.D.O. Hamilton (1995) Transformation of sweetpotato (Ipomoea batatas (L.) Lam.) with Agrobacterium tumefaciens and regeneration of plants expressing cowpea trypsin inhibitor and snowdrop lectin. Plant Sci. 107: 215-227.

Noh, S.A., H.S.Lee, Y.S.Kim, K.H.Paek, J.S.Shin and J.M.Bae (2013) Down-regulation of the IbEXP1 gene enhanced storage root development in sweetpotato. J. Exp. Bot. 64: 129-142.

O'Brien, P.J. (1972) The sweetpotato: Its origin and dispersal. American Anthropologist 74: 343-365.

Okada,Y., A.Saito, M.Nishiguchi, T.Kimura, M.Mori, K. Hanada, 
J. Sakai, C. Miyazaki, Y. Matsuda and T. Murata (2001) Virus resistance in transgenic sweetpotato [Ipomoea batatas L. (Lam.)] expressing the coat protein gene of sweetpotato feathery mottle virus. Theor. Appl. Genet. 103: 743-751.

Otani, M., M. Mii, T.Handa, H. Kamada and T. Shimada (1993) Transformation of sweetpotato (Ipomoea batatas (L.) Lam.) plants by Agrobacterium rhizogenes. Plant Sci. 94: 151-159.

Otani, M., T. Shimada, T. Kimura and A. Saito (1998) Transgenic plant production from embryogenic callus of sweetpotato (Ipomoea batatas (L.) Lam.) using Agrobacterium tumefaciens. Plant Biotechol. 15: 11-16.

Otani, M., Y.Wakita and T.Shimada (2001) Genetic transformation of sweetpotato (Ipomoea batatas (L.) Lam.) by Agrobacterium tumefaciens. Acta Hortic. 560: 193-196.

Otani, M., Y.Wakita and T. Shimada (2003) Production of herbicideresistant sweetpotato (Ipomoea batatas (L.) Lam.) plants by Agrobacterium tumefaciens-mediated transformation. Breed. Sci. 53: 145-148.

Otani, M., T. Hamada, K. Katayama, K. Kitahara, S.H. Kim, Y. Takahata, T. Suganuma and T. Shimada (2007) Inhibition of the gene expression for granule-bound starch synthase I by RNA interference in sweetpotato plants. Plant Cell Rep. 26: 1801-1807.

Park, E.J., Z. Jeknic, A. Sakamoto, J. DeNoma, R. Yuwansiri, N. Murata and T.H.H.Chen (2004) Genetic engineering of glycinebetaine synthesis in tomato protects seeds, plants, and flowers from chilling damage. Plant J. 40: 474-487.

Park, S.C., Y.H. Kim, J.C. Jeong, C.Y.Kim, H.S.Lee, J.W.Bang and S.S.Kwak (2011) Sweetpotato late embryogenesis abundant 14 (IbLEA14) gene influences lignification and increases osmotic- and salt stress-tolerance of transgenic calli. Planta 233: 621-634.

Park, S.C., Y.H. Kim, S.H. Kim, Y.J. Jeong, C.Y. Kim, J.S. Lee, J.Y. Bae, M.J.Ahn, J.C. Jeong, H.S. Lee et al. (2015a) Overexpression of the IbMYB1 gene in an orange-fleshed sweetpotato cultivar produces a dual-pigmented transgenic sweetpotato with improved antioxidant activity. Physiol. Plant. 153: 525-537.

Park, S.C., S.H.Kim, S.Park, H.U.Lee, J.S.Lee, W.S. Park, M.J.Ahn, Y.H.Kim, J.C. Jeong, H.S. Lee et al. (2015b) Enhanced accumulation of carotenoids in sweetpotato plants overexpressing IbOr-Ins gene in purple-fleshed sweetpotato cultivar. Plant Physiol. Biochem. 86: 82-90.

Prakash, C.S. and U.Varadarajan (1992) Genetic transformation of sweetpotato by particle bombardment. Plant Cell Rep. 11: 53-57.

Quan, R.D., M. Shang, H.Zhang, Y.X.Zhao and J.R.Zhang (2004) Engineering of enhanced glycine betaine synthesis improves drought tolerance in maize. Plant Biotechnol. J. 2: 477-486.

Ruan,L., L.J.Chen, Y.H.Chen, J.L.He, W.Zhang, Z.L.Gao and Y.H.Zhang (2012) Expression of Arabidopsis HOMEODOMAIN GLABROUS 11 enhances tolerance to drought stress in transgenic sweetpotato plants. J. Plant Biol. 55: 151-158.

Santa-Maria, M.C., C.G. Yencho, C.H.Haigler, W.F. Thompson, R.M. Kelly and B. Sosinski (2011) Starch self-processing in transgenic sweet potato roots expressing a hyperthermophilic $\alpha$-amylase. Biotechnol. Prog. 27: 351-359.

Schafleitner, R., L.R. Tincopa, O. Palomino., G. Rossel, R.F. Robles, R.Alagon, C.Rivera, C.Quispe, L.Rojas, J.A. Pacheco et al. (2010) A sweetpotato gene index established by de novo assembly of pyrosequencing and Sanger sequences and mining for genebased microsatellite markers. BMC Genomics 11: 604.

Shimada, T., M. Otani, T.Hamada and S.H.Kim (2006) Increase of amylose content of sweetpotato starch by RNA interference of the starch branching enzyme II gene (IbSBEII). Plant Biotechnol. 23:
85-90.

Shin, J.S., K.M.Kim, D.J.Lee, S.B.Lee, N.R.Burgos and Y.I.Kuk (2011) Resistance levels and fitness of glufosinate-resistant transgenic sweetpotato in field experiments. Field Crops Res. 121: 324-332.

Sivparsad, B.J. and A. Gubba (2014) Development of transgenic sweetpotato with multiple virus resistance in South Africa (SA). Transgenic Res. 32: 377-388.

Song, G.Q., H.Honda and K.I.Yamaguchi (2004) Efficient Agrobacterium tumefaciens-mediated transformation of sweet potato (Ipomoea batatas (L.) Lam.) from stem explants using a two-step kanamycin-hygromycin selection method. In Vitro Cell. Dev. Biol., Plant 40: 359-365.

Tan, J.L., C.Y.Wang, B. Xiang, R.H.Han and Z.F. Guo (2013) Hydrogen peroxide and nitric oxide mediated cold- and dehydrationinduced myo-inositol phosphate synthase that confers multiple resistances to abiotic stresses. Plant Cell Environ. 36: 288-299.

Tanaka, M., Y.Takahata, H. Nakayama, M.Nakatani and M. Tahara (2009) Altered carbohydrate metabolism in the storage roots of sweetpotato plants overexpressing the $S R F 1$ gene, which encodes a Dof zinc finger transcription factor. Planta 230: 737-746.

Tao, X., Y.H.Gu, H.Y.Wang, W.Zheng, X.Li, C.W.Zhao and Y.Z. Zhang (2012) Digital gene expression analysis based on integrated de novo transcriptome assembly of sweet potato [Ipomoea batatas (L.) Lam.]. PLoS ONE 7: e36234.

Tao, X., Y.H.Gu, Y.S.Jiang, Y.Z.Zhang and H.Y.Wang (2013) Transcriptome analysis to identify putative floral-specific genes and flowering regulatory-related genes of sweet potato. Biosci. Biotech. Biochem. 77: 2169-2174.

Ukoskit, K.T. and P.G. Thompson (1997) Autopolyploidy versus allopolyploidy and low-density randomly amplified polymorphic DNA linkage maps of sweetpotato. J. Am. Soc. Hortic. Sci. 122: 822828.

Wakita,Y., M.Otani, T.Hamada, M.Mori, K.Iba and T.Shimada (2001) A tobacco microsomal $\omega-3$ fatty acid desaturase gene increases the linolenic acid content in transgenic sweet potato (Ipomoea batatas). Plant Cell Rep. 20: 244-249.

Wang, B., H.Zhai, S.Z.He, H.Zhang, Z.T.Ren, D.D.Zhang and Q.C.Liu (2016a) A vacuolar $\mathrm{Na}^{+} / \mathrm{H}^{+}$antiporter gene, IbNHX2, enhances salt and drought tolerance in transgenic sweetpotato. Sci. Hortic. 201: 153-166.

Wang, H.X., W.J.Fan, H.Li, J. Yang, J.R. Huang and P.Zhang (2013a) Functional characterization of dihydroflavonol-4-reductase in anthocyanin biosynthesis of purple sweetpotato underlies the direct evidence of anthocyanins function against abiotic stresses. PLoS ONE 8: e78484.

Wang,H.X., J.Yang, M.Zhang, W.J.Fan, N.Firon, S.Pattanaik, L. Yuan and P.Zhang (2016b) Altered phenylpropanoid metabolism in the maize Lc-expressed sweetpotato (Ipomoea batatas) affects storage root development. Sci. Rep. 6: 18645.

Wang, L.J., S.Z.He, H. Zhai, D.G. Liu, Y.N. Wang and Q.C. Liu (2013b) Molecular cloning and fanctional characterization of a salt toleranceassociated gene IbNFU1 from sweetpotato. J. Integr. Agric. 12: $27-35$.

Wang, Y.N., Y.Li, H.Zhang, H.Zhai, Q.C.Liu and S.Z.He (2016c) A plastidic ATP/ADP transporter gene, IbAATP, increases starch and amylose contents and alters starch structure in transgenic sweetpotato. J. Integr. Agric. 15: 1968-1982.

Wang, Z.Y., B.P.Fang, J.Y.Chen, X.J.Zhang, Z.X.Luo, L.F.Huang, X.L.Chen and Y.J.Li (2010) De novo assembly and characterization of root transcriptome using Illumina paired-end sequencing 
and development of cSSR markers in sweetpotato (Ipomoea batatas). BMC Genomics 11: 726 .

Welford, R.W., I.J. Clifton, J.J. Turnbull, S.C. Wilson and C.J. Schofield (2005) Structural and mechanistic studies on anthocyanidin synthase catalysed oxidation of flavanone substrates: the effect of C-2 stereochemistry on product selectivity and mechanism. Org. Biomol. Chem. 3: 3117-3126.

Woolfe, J.A. (1992) Sweetpotato: An untapped food resource. Cambridge University Press, Cambridge, UK, pp. 118-187.

Xie, F.L., C.E. Burklew, Y.F. Yang, M.Liu, P.Xiao, B.H.Zhang and D.Y.Qiu (2012) De novo sequencing and a comprehensive analysis of purple sweet potato (Ipomoea batatas L.) transcriptome. Planta 236: 101-113.

Xie,Z.Y. and G.S. Yang (2003) Advances in salt tolerance of forage plants. Pratacult. Sci. 20: 11-17.

Xiong, L.M., M. Ishitani, H. Lee and J.K.Zhu (2001) The Arabidopsis LOS5/ABA3 locus encodes a molybdenum cofactor sulfurase and modulates cold stress- and osmotic stress-responsive gene expression. Plant Cell 13: 2063-2083.

Yang, Q., Z.Z.Chen, X.F.Zhou, H.B. Yin, X.Li, X.F.Xin, X.H.Hong, J.K.Zhu and Z.Z. Gong (2009) Overexpression of SOS (salt overly sensitive) genes increases salt tolerance in transgenic Arabidopsis. Mol. Plant 2: 22-31.

Yang, X.H., Z.Liang and C.M.Lu (2005) Genetic engineering of the biosynthesis of glycinebetaine enhances photosynthesis against high temperature stress in transgenic tobacco plants. Plant Physiol. 138: 2299-2309.

Yeh, K.W., M.I. Lin, S.J. Tuan, Y.M.Chen, C.J.Lin and S.S. Kao (1997) Sweetpotato (Ipomoea batatas) trypsin inhibitors expressed in transgenic tobacco plants confer resistance against Spodoptera litura. Plant Cell Rep. 16: 696-699.

Yi, G., Y.M. Shin, G.Choe, B.Shin, Y.S. Kim and K.M.Kim (2007) Production of herbicide-resistant sweetpotato plants transformed with the bar gene. Biotechnol. Lett. 29: 669-675.

Yu, B., H.Zhai, Y.P. Wang, N.Zang, S.Z.He and Q.C.Liu (2007) Efficient Agrobacterium tumefaciens-mediated transformation using embryogenic suspension cultures in sweetpotato, Ipomoea batatas (L.) Lam. Plant Cell Tissue Organ Cult. 90: 265-273.

Yu, H., X. Chen, Y.Y.Hong, Y. Wang, P. Xu, S.D. Ke, H.Y.Liu, J.K. Zhu,
D.J.Oliver and C.B.Xiang (2008) Activated expression of an Arabidopsis HD-START protein confers drought tolerance with improved root system and reduced stomatal density. Plant Cell 20: 1134-1151.

Yu,L., H.Zhai, W.Chen, S.Z.He and Q.C.Liu (2013) Cloning and functional analysis of lycopene $\varepsilon$-cyclase (IbLCYe) gene from sweetpotato, Ipomoea batatas (L.) Lam. J Integr. Agric. 12: 773 780.

Yu,X.X., N.Zhao, H.Li, Q.Jie, H.Zhai, S.Z.He, Q.Li and Q.C.Liu (2014) Identification of QTLs for starch content in sweetpotato (Ipomoea batatas (L.) Lam.). J. Integr. Agric. 13: 310-315.

Zang, N., H.Zhai, S. Gao, W.Chen, S.Z.He and Q.C.Liu (2009) Efficient production of transgenic plants using the bar gene for herbicide resistance in sweetpotato. Sci. Hortic. 122: 649-653.

Zhai, H. and Q.C.Liu (2003) Studies on the genetic transformation of embryogenic suspension cultures in sweetpotato. Sci. Agric. Sin. 36: 487-491.

Zhai,H. and Q.C.Liu (2009) Expression analysis of sweetpotato myo-inositol-1-phosphate synthase gene. Mol. Plant Breed. 7: 537-544.

Zhai,H., F.B.Wang, Z.Z.Si, J.X.Huo, L.Xing, Y.Y.An, S.Z.He and Q.C.Liu (2016) A myo-inositol-1-phosphate synthase gene, IbMIPS1, enhances salt and drought tolerance and stem nematode resistance in transgenic sweet potato. Plant Biotechnol. J. 14: 592 602.

Zhang, N., H. Si, G. Wen, H.Du, B. Liu and D. Wang (2011) Enhanced drought and salinity tolerance in transgenic potato plants with a $B A D H$ gene from spinach. Plant Biotechnol. Rep. 5: 71-77.

Zhang, Y.F., Q.Ji, Y.J.Xing, Q.Li, X.Wang, C.Xu and C.X.Huang (2013) Expression of an engineered tandem-repeat starch-binding domain in sweetpotato plants. Afr. J. Biotechnol. 12: 5994-5999.

Zhao, N., X.X.Yu, Q.Jie, H.Li, H.Li, J.Hu, H.Zhai, S.Z.He and Q.C.Liu (2013) A genetic linkage map based on AFLP and SSR markers and mapping of QTL for dry-matter content in sweetpotato. Mol. Breed. 32: 807-820.

Zhou, W., C.T.Huang, Y.F. Gong, Q.L.Feng and F. Gao (2010) Molecular cloning and expression analysis of an ANS gene encoding anthocyanidin synthase from purple-fleshed sweetpotato (Ipomoea batatas (L.) Lam.). Plant Mol. Biol. Rep. 28: 112-121. 